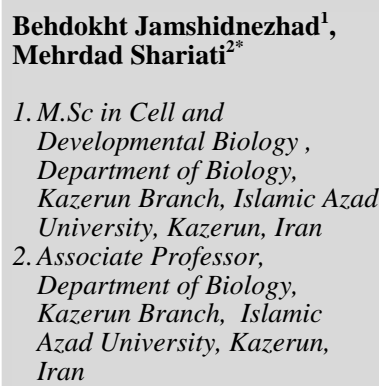

\section{Effect of Primidone on Pituitary-Thyroid Axis and Thyroid Tissue Changes in Newborn Male Rats from Mothers}

Received:31 Jan. 2017; Accepted:28 Feb. 2018

\section{Abstract}

Background: Thyroid is an important organ with special function in metabolism of drugs. Primidone is a drugs for treatment of some patients including epilepsy. The present study was conducted to evaluate the effect Primidone on thyroid hormones function including T3,T4 and TSH and histological changes of thyroid newborn male rats.

Material and Methods: In this experimental study, 40 newborn male rats wistar strain divided into 5 group of 8 .The newborns were taken from pregnant mothers divided to the control group, the sham group and three experimental groups that received 20, 40 and 60 $\mathrm{mg} / \mathrm{kg}$ b.w. primidone in the pregnancy period for 21 days orally. In 25 days after parturition, the newborns weighted and T3,T4 and TSH hormone assay. The newborns thyroid tissue evaluated by H\&E histological staining methods.

Results: Body weight and thyroid weight in different experimental groups show did not significant difference compared to the control group. Concentration of TSH and T3 hormones in different experimental groups show did not significant difference compared to the control group. Also, serum level of T4 hormone in experimental groups 2,3 show a significant decrease compared to the control group. In tissue tissue samples with increasing doses of the drug was observed more necrosis.

Conclusion: Primidone has destructive effects on Thyroid gland.

Keywords: Primidone, T3, T4, TSH, Newborn Male Rat 


\section{تأثير ثيريميدون بر محور هيبوفيز - تيروئيد و تغييرات بافتى تيروئيد در نوزادان موش صحر ايى نر متولد شده از مادران}

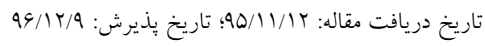

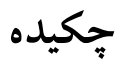

زمينه و هدف: تيروئيد يكى اندام با عملكرد اختصاصى در متابوليسم داروهاست. يريميـدون دارويسى بــراى درمـان برخىى

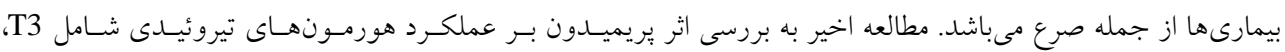

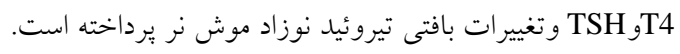

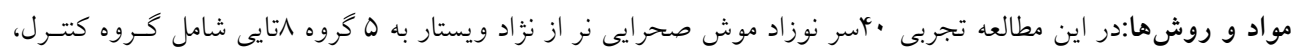

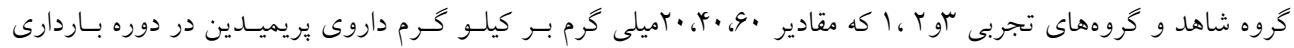

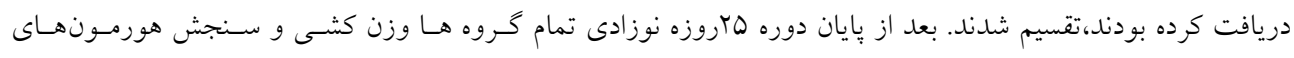

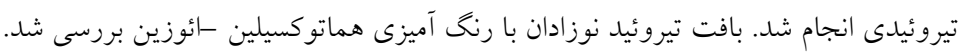

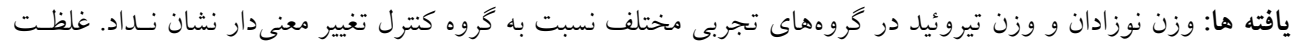

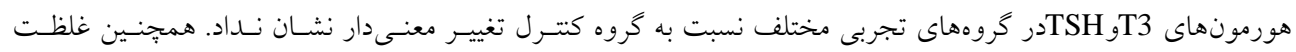

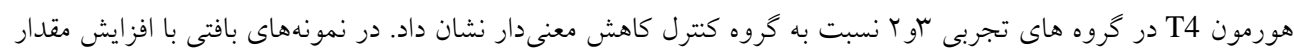

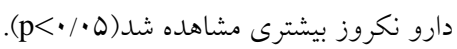

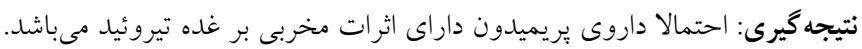
كلمات كليدى: بريميدون TSH ,T3, T4 نوزاد نر موش صحرايى roهدخت جمشيد نزاد'، مهرداد شريعتى

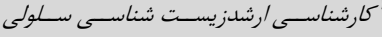

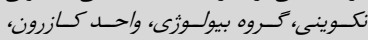

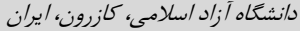

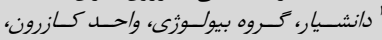

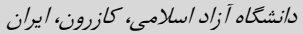


اختلال در عملكرد ساير اندامهاى مختلف بدن مىشود.

در تحقيق حاضر تلاش بـر آن بـوده كـه اثــرات جـانبى داروى يريميدون بر غلظت هورمونهاى T3، TSH و TS4 وهم:تين تغييرات بافتى تيروئيد در نوزادان نر موش صحرايى در مدت بr روز مـورد بررسى قرار گيرند تا نتـايج حاصـل از ايسن يـزوهش بتوانسـ مـورد

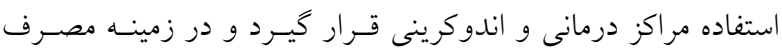
بهينه از اين دارو بيش بينىهاى لازم انجام شود.

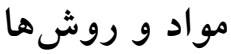
حيوانات

حيوانات مورد استفاده دراين تحقيق ·ץ سـر نـوزاد مـوش هـاى صحرايى نر نزاد ويستار با وزن تقريبى •ه گرم و سـن باب روز بـود

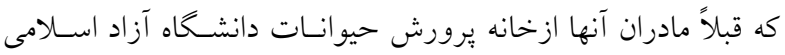
واحد كازرون تهيه و در طى دوره باردارى داروى ثريميدون به آنها

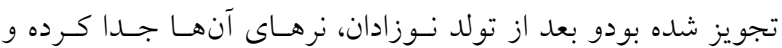
درهمان مركز نخهارى شدند. درجه حرارت محيط r T Y Y درجسه

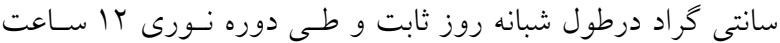
تاريكى و r ا ساعت روشنايى قــرار داشـتند. قفـس هــاى نخهـدارى

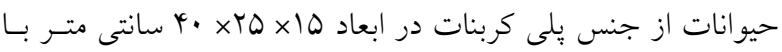

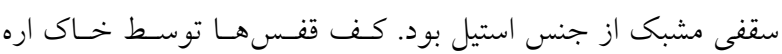
مفروش شده بود و خاك ارههاى موجود در كـف قفسسهـا هـر دو روز توسط آب و مواد ضد عفونى شستشو مىشدند. آب موشها از

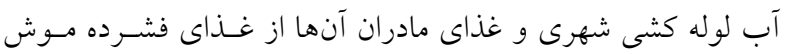
ساخت شركت سهامى خوراى دام هورمونهاى تيروئيدى از شركت

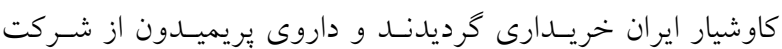
دارويى دارو بخخش تهيه گرديد.

\section{تيمار حيوانات}

در اين مطالعه تجربى • ب سر نوزاد موش صسحرايى نـر از نـزاد

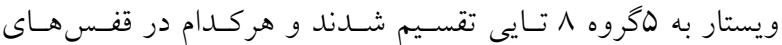
جداگانه و در يك شرايط نخهارى شدند.كروه كنترل شـامل ^ سـر نوزاد موش صحرايى نر ازمادرانى كـه در دوره بـاردارى در شــرايط عادى بدون دريافت دارو نخهدارى شدند.كروه شاهد شـامل ^م سـر
يريميدون درسـال 1904 بــراى اولـين بــار بـه عنـوان يكسى از داروهاى ضد صرع معرفى شد و مورد استفاده مبتلايان به صرع قرار كُرفت.' در بجهه هايى با حملات اوليه صرع اين دارو به آنهـا تجـويز شـــ. يريميـدون دارويسى بـا فرمـول

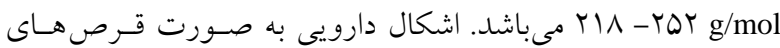

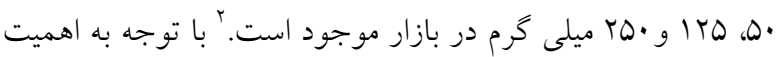
رشد در كودكان بررسى اثرات جانبى يريميدون مهم مىباشد كه اين

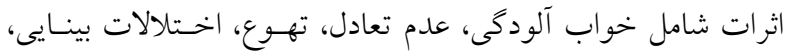
افسردگى، تحريكى يذيرى ،بيقرارى در سالمندان،هيجانات و فعاليت

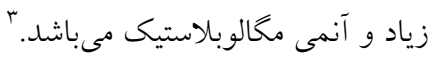

مـادرانى كـه در دوران حـاملكى ازايسن دارو اسـتفاده مسى كنتـــ استعداد بيشترى براى تولد بجهه هاى ناقص الخلقه دارند. آنومالى هاى ناشى ازاين دارو مانند سندرم فنسى تـوئين اسـت. مصـرف طـولانى مدت يريميدون قدرت بارورى را كاهش مىدهد و در بجههـاى در حال رشد كه سيستم اسكلتى شان در حال تشكيل اسـت بريميـدون به تلدريج با اثر كذارى بر روى مراكـز اسـتخوان سـاز باعـث ايجـاد

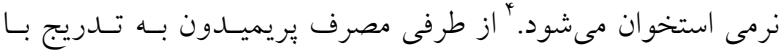
كاهش ترشح ايى نفرين و سروتونين باعث ايجاد افسردگى مىشود. تجمع يريميدون در كبد باعث سيروز كبدى مسىشـود و اخـتلال در

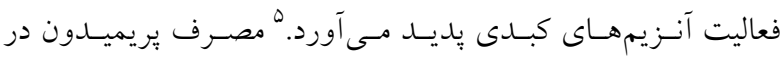

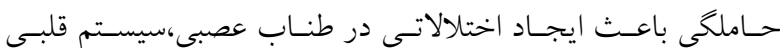
عروقى،شكاف دهانى ،آسيب هاى مسير ادرارى در جنين مىشـود و حتى مصرف ويتامين هاى مكمل از اين عوارض بيشخيرى نمى كند. مادرانى كه از يريميدون استفاده مى كنند به خاطر توزيـع بريميـدون

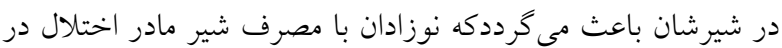
انعقاد خون كه مشابه كمبود ويتامين K است نشان دهند. مطالعات نشان مى دهـــ غــده تيروئيـــ يكـى از مهمتـرين غــد اندوكرين بدن محسوب مى شودو در تنظيم ميـزان كلسى متابوليسـم بدن از جمله اساسى ترين جزءآن يعنى مصرف اكسيزن، در رشـــ و نمو دستخاه عصبى در دوران جنينى و عملكرد بسيارى از اندامهـاى لرئ

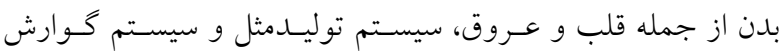
نقش دارد.`^هر گونه اخـتلال در عملكــرد ايسن غـده باعـث ايجـاد 


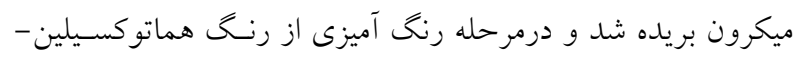

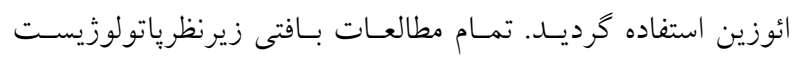

$$
\text { صورت كرفت. }
$$

$$
\text { آناليز آمارى }
$$

نتايج حاصل از اين مطالعه با استفاده از نرم افزار آمـارى SPSS

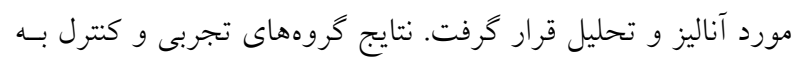

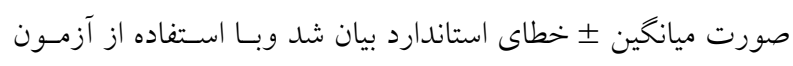
ANOVA

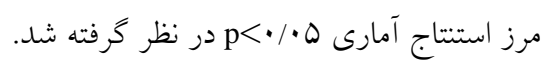

\section{نتايج}

يافته هاى اين مطالعه نشان دادكه اختلاف معنى دارى بـين كـروه

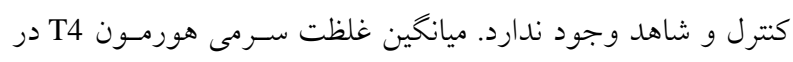

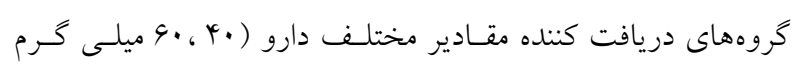

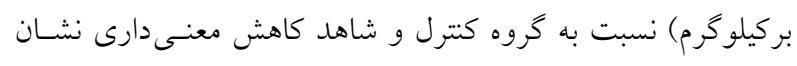

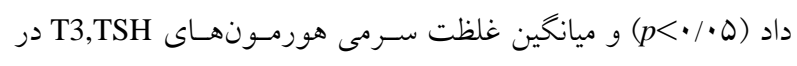

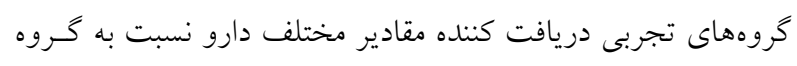
كنترل و شاهد اختلاف معنىدارى نشان نداد. ميـانخين وزن تيروئيسـ

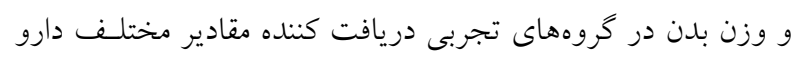

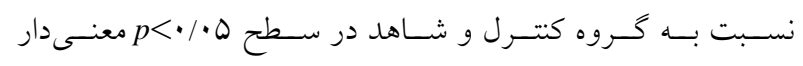

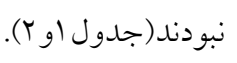

نوزاد موش صحرايى نر ازمادرانى كه در دوره باردارى روزانه حلال

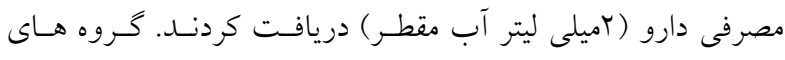

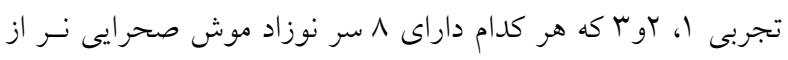

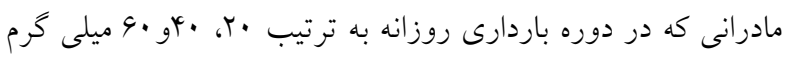

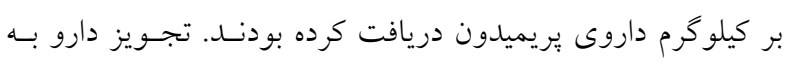

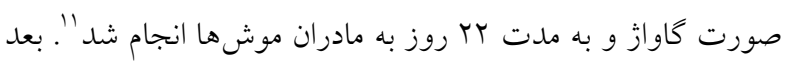

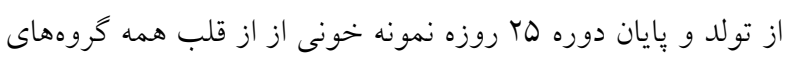

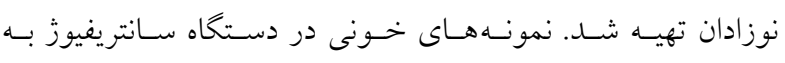

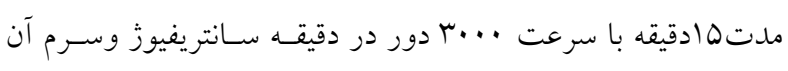

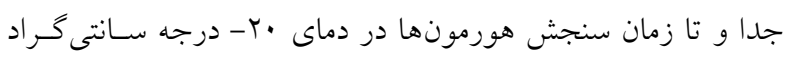

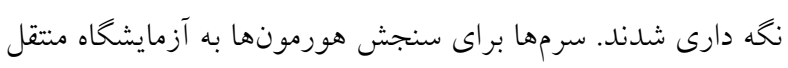

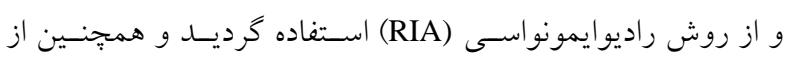
كيتهاى مخصوص اندازه كيرى هورمـونهـاى تيروئيسـى سـاخت شركت كاوشيار ايران استفاده كرديد.

\section{آزمايش هاى بافت شناسى}

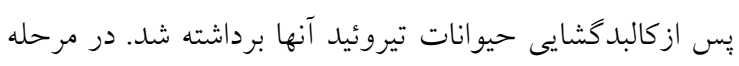

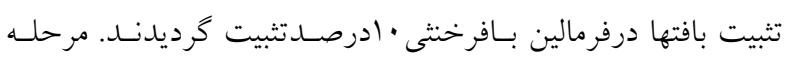

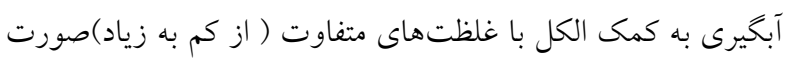

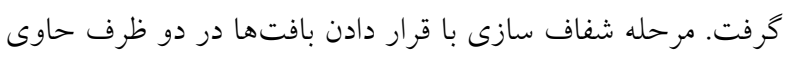

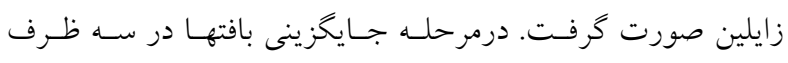

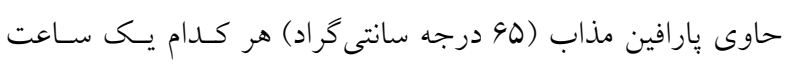

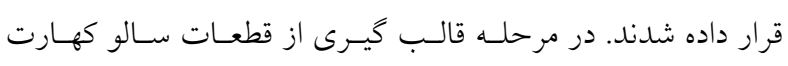

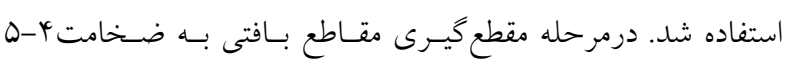

\begin{tabular}{|c|c|c|c|}
\hline TSH(miu/ml) & T4(ng/ml) & T3(pg/ml) & كروهها \\
\hline$\varphi / \wedge 9 \pm \cdot / 1 V$ & $|Y / V 9 \pm \cdot / 1|$ & $V M r / I \pm V / \cdot 9$ & كنترل \\
\hline$r / 4 q \pm \cdot / 14$ & $\mid r / Y 4 \pm \pm . / T$ & VYT/VIII/Or & شاهد \\
\hline $4 / 09 \pm \cdot / 19$ & $\mid r / r q \pm \cdot / r r$ & $V \Delta V / V \pm|1 / 4|$ & تجربى ا(mg/kg20) \\
\hline$r / 9 \cdot \pm \cdot / r$. & $|r / q \cdot \pm \cdot / r| r r$ & $V Y q / V \pm G / Y Y$ & تجربى r(mg/kg40) \\
\hline$Q / T V \pm \cdot / T \cdot$ & $1 \cdot / 9 V \pm \cdot / r V$ & $V / \Psi / \Lambda \pm V / \Delta \Delta$ & تجربى ץ(mg/kg60) \\
\hline
\end{tabular}

جدول ا: تأثير بريميدون بر ميانكين غلظت سرمى هورمونهاى تيروئيدى حيوانات مورد آزمايش 
جدول Y: تأثير بريميدون بر تغييرات وزن بدن و تيروئيد

\begin{tabular}{|c|c|c|}
\hline وزن تيروئيد(g) & وزن بدن(g) & كروهها \\
\hline$\cdot / \cdot \wedge \pm \cdot / \cdot \cdot r$ & $q \cdot / r \cdot \pm I r / M \Lambda$ & كنترل كن \\
\hline$\cdot / \bullet \pm \pm \cdot \cdot \cdot \Delta$ & $1 \cdot \wedge / \wedge \wedge \pm \wedge / \cdot 9$ & شاهد \\
\hline$\cdot / \cdot \wedge \pm \cdot / \cdot \cdot v$ & $1 \cdot \Delta \pm 1 \cdot / r$. & تجربى (mg/kg20) \\
\hline$\cdot / \cdot \pm \cdot / \cdot \cdot 1$ & $Q 9 / \Lambda \Lambda \pm \varphi / r \mid$ & تجربى ץ (mg/kg40) \\
\hline$\cdot / \cdot \Lambda \pm \cdot / \cdot r$ & $q \Lambda / r \Delta \pm r / q$. & تجربي r (mg/kg60) \\
\hline
\end{tabular}

مقايسه با گروه كتترل بـدون تغييـر و در گـروه تجربسى متوسط در

نتايج حاصل از مطالعات بافت شناسى

مقايسه با كروه كنترل دجارمقدار بيشتر آسيب و كاهش گرديده است

به منظور بررسى اثر يريميدون بر روى بافت تيروئيسد، يسس از

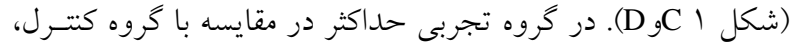

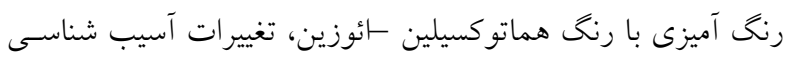
ميزان بهم خوردن آرايش سلولى،كاهش كلوئيدهـاى درون تيروئيسـ

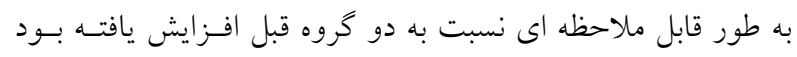

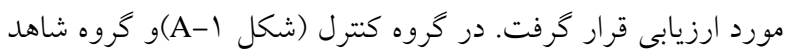
(شكل (B-1) شكل ، قطر و فوليكولهاى بافت تيروئيد فاقد آسيب

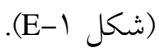
و سلولها كاملا سالم و طبيعى بودند. در كروه تجربى حداقل فوليكولها و كلوئيسـ درون تيروئيسـ در

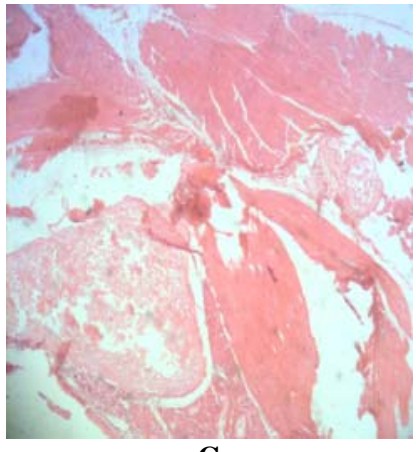

C

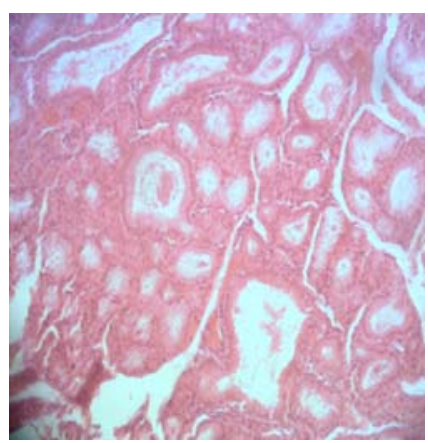

B

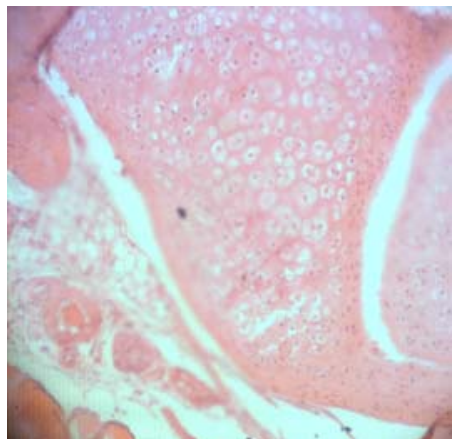

A

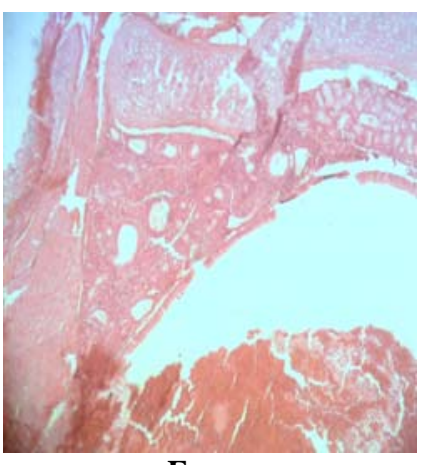

E

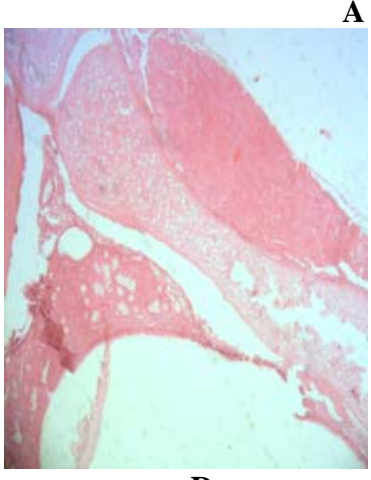

شكل ا: فتوميكرو گراف مقاطع عرضى بافت تيروئيد در گروه هاى مختلف بزرخنمايى •او رنخ آميزى A. E\&H خروه كتــرل : فوليكـولهـا و

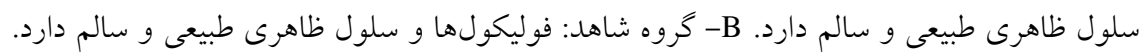

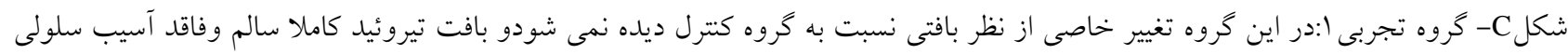

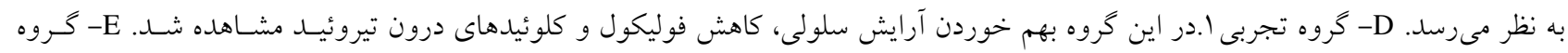

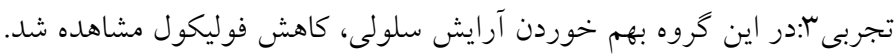


دانسته اند اغلب اين بررسىها اختلالى را در محور هييوتـالاموس -

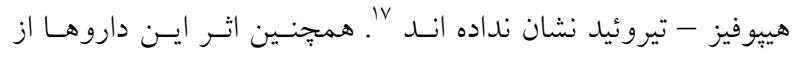
جمله يريميدون در بايين آوردن T4سرم در سنين بـايين تـر بـارزتر

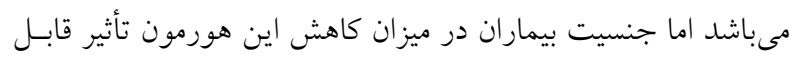

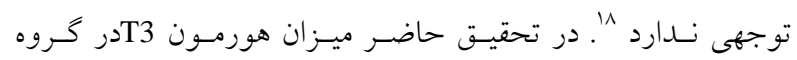

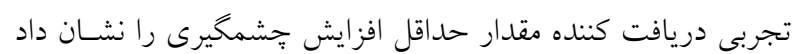
كه اين افزايش معنىدار نبود احتمالا بريميدون از طريق تأثير بر غده

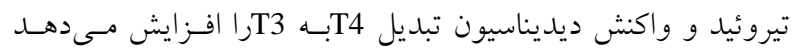
وباعث افزايش اين هورمون شده اسـت. مطالعـات نشـان مسىدهـــ

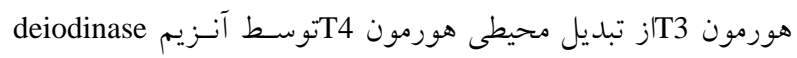
ايجاد مى گردد و حدود •لمدرصد اين عمل در كبد انجـام مسى شـود. بنابراين از اثرات مخرب بر هياتوسيتهاى كبدى جلو گيرى كـرده و

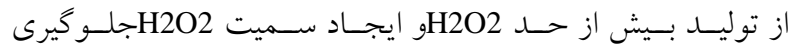
مى كند. 'مطالعات در يك بررسى روى تأثير داروهاى ضد صرع بـر

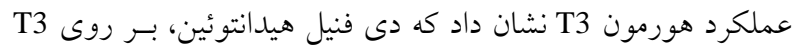

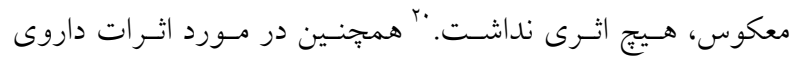
يريميدون بر روى T3سرم نتـايج مطالعـات مختلـف متفــاوت بـوده است اما به طور كلى در بيشتر مطالعات سطح سرمى ايسن هورمـون

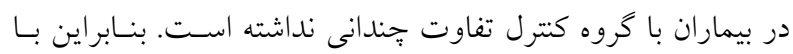
توجه به نتايج بدست آمده و تحقيقات ساير محققان مسىتـوان ايسن

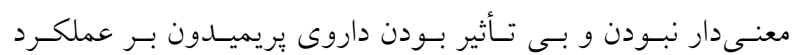

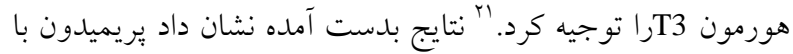
مقادير مختلف غلظت هورمون TSHرابه صورت معنسى دارى تغييـر نمى دهد. مطالعات ساير محققان نشان مسىدهــ تغييـر هموسـتازى هورمون تيروئيد بوسـيله بريميـدون، فنسى تـوئين و كاربامـازيين در

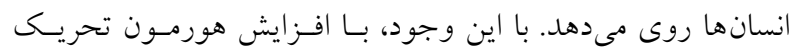
كننده تيروئيد (TSH) مرتبط نيست و اهميـت بـالينى تغييـر مقـادير سرم هورمونهاى تيروئيدى با اين داروهاى ضد صسرع، نامشـصص

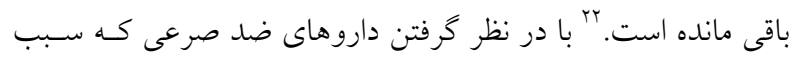

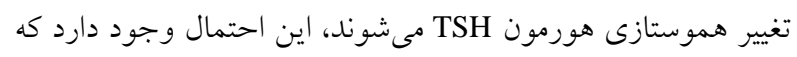

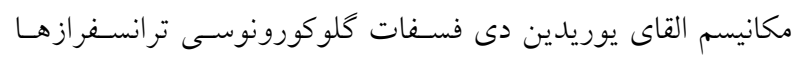
دخالت داشته يا حداقل داراى دخالت كمى در ايسن تغييـر

باشد.
در تحقيق حاضر تأثير، اثر داروى بريميـدون برتغييـرات بافـت شناسـى و غلظـت هورمـونهــاى مكورد بررسسى قـرار كرفت. يريميدون در مقادير متوسط و حداكثر، غلظت هورمون T4را

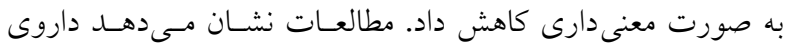
يريميدون بر روى هورمون T4 در كودكان مبتلا بـهـ صـرع در طـول درمان كوتاه مدت هيج اثـرى بـر روى تسـت مربـوط بـه عملكـرد

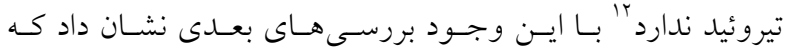
يريميدون مىتواند موجب كم كارى تيروئيد بدون نشانه بالينى گردد و در نهايست منجسر بـه كـاهش تيروكسـين كـردد. ايسن امـر نشـان

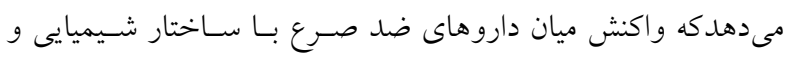
متابوليسم هورمون تيروئيدى متفاوت مىباشد. يكى از مراحل سـنتز هورمونهاى تيروئيدى سنتز ريشههاى تيروزيل است كه در ابتدا بــه صورت اجزايى از يك ملكول يروتئينى بزرگ به نـام تيرو گلوبـولين

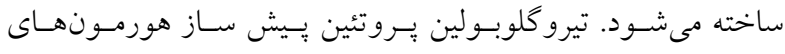

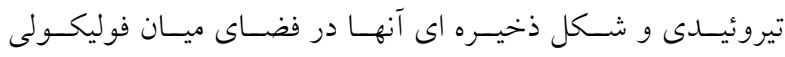

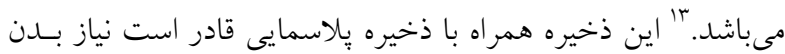

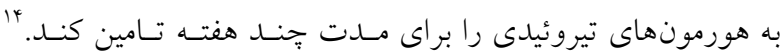

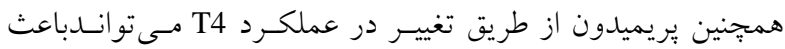
كاهش در غلظت هورمون تيروكسين (T4) شود. منبع T4 تنها غـده تيروئيد است اما در مورد T3 اينخونه نيست و تنها يك جهارم ميزان

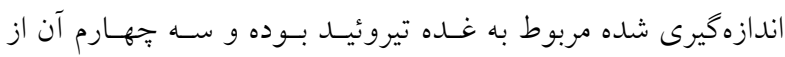

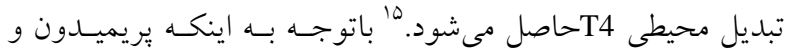

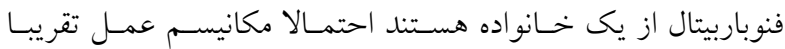

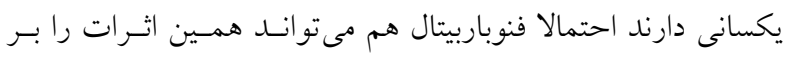
اعمال كند و منجر به كاهش هورمون تيروكسين در طولانى مدت فوبست كرد.د.

با توجه بـه اتــرات داروهـاى ضـــ صـرع از جملـه يريميـدون، فنوباربيتـال و كاربامـازيين روى سيستم اعصـاب مركـزى ،برخـى

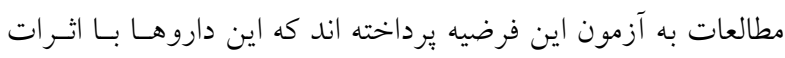
مركزى و تأثير بر روى محسور هيبوتـالاموس - هيبـوفيز -تيروئيسـ باعث كاهش سطح سرمى T4مى شوند. به غير از مطالعات معدودى كـه اخـتلال مركـزى را عامـل كـاهش T4 ســرم در ايسن بيمـاران 
حداكثر بر فعاليت محور هييوفيز -تيروئيد تأثير مى گـذارد و باعـث

كاهش هورمون T4مى شود. همجيخين با توجسه بـه معنسى دار نبـودن

هورمونهاى TSH، T3 مطالعات بيشترى در اين زمينـه لازم اسـت. احتمال مىرود يُ از كاهش T4Tر زمـان كوتـاه آزمـايش ،آرايسش

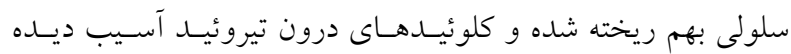

\section{نتيجه گيرى كلى}

$$
\begin{aligned}
& \text { احتمالا داروى بريميدون با مقــادير اسـتفاده شـــه داراى اتــرات } \\
& \text { مخربى بر تكوين غده تيروئيد نوزادان موش صحرايى نرمتولد شـده } \\
& \text { از مادران مىباشد، هر جنــد مطالعـات بيشـترى در ايـن زمينـه لازم } \\
& \text { تشكر و قدر دانى }
\end{aligned}
$$

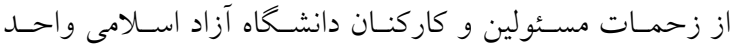

$$
\begin{aligned}
& \text { كازرون، آزمايشگاه تشخيص طبى دكتر قوامى شيراز و سـركار خـانم }
\end{aligned}
$$

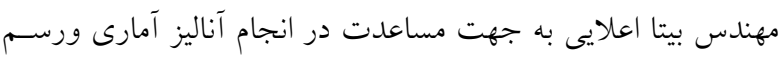

$$
\begin{aligned}
& \text { نمودارهاى كامييوترى تشكر و قدردانى مىشود. }
\end{aligned}
$$

\section{References}

1. Wyeth Timeline. About Wyeth. Retrieved 2007; 11:11.

2. Zesiewicz T. A, R. Elble E.D, Louis R. A, Hauser K.L, et al. Therapies for essential tremor: Report of the Quality Standards Subcommittee of the American Academy of Neurology". Neurology 2005; 64 (12): 2008.

3. Y. Newman - Tancredi, D. Cussac, Y, Quentric, M. Touzard, L .Verriele and N. Carpentier et al. , Differential actions of antiparkinson agents at multiple classes of monoaminergic receptor. III. Agonist and antagonist properties at serotonin , 5 -HT (1) and 5 HT(2) , receptor subtypes . J Pharmacol Exp Thar 2009 : $815-822$

4. Henandez Diaz S, werler MM ,walker Am , Mitchell AA. Neural tube defect relation to use of folic acid and agonists during pregnancy .Slone Epidemiology unit. Boston university school of public health , Brookline , MA 02446 , USA .Shernan@bu 2009 ;153(10):961-8 .

5. Katano H, Fukushima T, Karasawa K, Sugiyama N, Ohkura A, Kamiya K. Primidone-induced hyperammonemic encephalopathy in a patient with

$$
\begin{aligned}
& \text { ترشح TSHبه طور عمده توسط آزاد شده از هييوتالاموس } \\
& \text { كنترل مىشود وهورمونهـاى تيروئيسـى سـاخت رSH را در سـطح }
\end{aligned}
$$

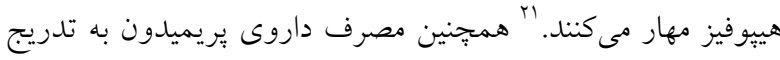

$$
\begin{aligned}
& \text { با كاهش ترشح سروتونين باعث افـزايش ترشـح TSH مسىشـود و } \\
& \text { عمل تحريك مسير سروتونرزيك بر روى ترشح TSH كزارش شده } \\
& \text { است. } \\
& \text { احتمالا داروى بريميدون بــر هيسـتومورفولوزى غــده تيروئيـــ } \\
& \text { يعنى قطر،شكل فوليكـولهـاى بافـت تيروئيــ ،كلوئيسـهـاى درون }
\end{aligned}
$$

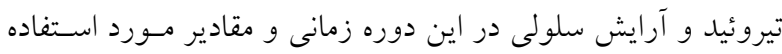

$$
\begin{aligned}
& \text { تأثير كذار است .سلولهاى فوليكولى طرحى بـراى سـنتز و ترشـح } \\
& \text { هورمونهاى تيروئيدى هسـتند هورمـون T3فـرم فعـال بيولـوزيكى }
\end{aligned}
$$

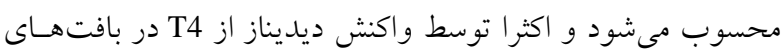

$$
\begin{aligned}
& \text { خارج تيروئيدى نظير كبد ايجاد مىشود. هورمون تيروكسين تنها در }
\end{aligned}
$$

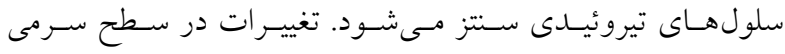

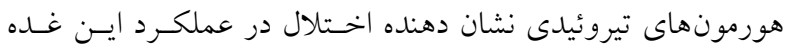

$$
\begin{aligned}
& \text { محسوب مىشود. همجنين تيروئيد تنها انـامى اسـت كـه هورمسون }
\end{aligned}
$$

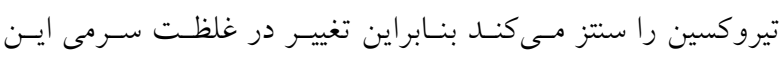

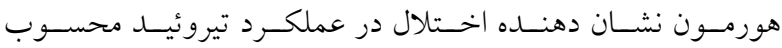

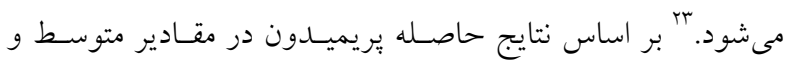

cerebral astrocytoma. J Clin Neurosci. 2002;9(1):79-81.

6.Audi SH , Dawson CA , Iinehan JH , Krenz GS ,Ahlf SB , Roerig DI , An interpreted of 14 c-urea and 14cprimidone extraction in isolated rabbit lungs. Annals of Biomedical Engineering 1996: 337-351.

7. Esser KJ, kotlarek F, Habedand M, muhler U, muhler E. Chromosomal investigations in epileptic children during long -term therapy with phenytoin or primidone. 2009; 53(3):345-348 .

8. Guyton and Hall. Text book of medical physiology. 2006. pp.1455-1470.

9. Farhana Ahad and Shaiq A. Ganie Iodine, Iodine metabolism and Iodine deficiency disorders revisited. Indian J Endocrinol Metab. 2010; 14(1): 13-17.

10. Beme Levy. Principles of physiology. Fourth Edition. 2005.pp. 663.

11. Bentsen KD , Gram L, Veje A. Serum T3 and blood folic acid during monotherapy with primidone or Phenobarbital. Acta Neurol Scand 1998 ;67:235-241. 
12. Fichsel H, Konpflle G. The effect of primidone treatment of thyroid hormones in epileptic children and adolescents(authors transl)].Monastsschr Kinderheilkd. 1977;125(8):791-6.

13. Cullen, M.J, Burger A.G, Ingbar, S.H. Effects of diphenylhydantoin on peripheral thyroid hormone economy and the conversion of T4. Israel Journal of Medical Sciences 1973; 8:1868.

14. Chin W, Schussler G.C. Decreased serum free thyroxine concentration in patients treated with diphenylhydantoin. Journal of Clinical Endocrinology and Metabolism 2004; 28:181-186.

15. Cavalieri R.R, Sung L.C. Becker C. E. Effects of primidone on thyroxine Kinetics in Graves disease. Journal of Clinical Endocrinology and Metabolism 1973; 37: 308-316.

16. Schroder JP, Hiede D, Bent C, Kaptein E. Effects of 5,5 diphenylhydantoin on the thyroid status in rats. Eur $\mathrm{J}$ Endocrinol. 1998;134(2):221-4.

17. Yoshida T, Tanaka M, Suzuki Y, Sohmiya M, Okamoto K. Antioxidant properties carbamazepine and primidone: inhibition of brain auto-oxidation protection of microglial cells in rats. Neurosci Lett;2009:330(1):1-4.

18. Isojarvi J.I.T, Pakarinen A.J, Myllyla V. Thyroid function in epileptic patients treated with primidone. 2007;1175:46-75.

19. Smith PJ, Surks MI. Multiple effects of carbamazepine, primidone and phenytoin on serum levels of thyroid hormones and thyrotropin in humans. Scand J Clin Lab Invest. 2008; 38:731-736.

20. Loscher W, Schmidt D. Increase of human plasma GABA by primidone. Epilepsia 2001;611:5-21.

21. Bentsen KD, Gram L, Veje A. Serum T3 and blood folic acid during monotherapy with primidone or Phenobarbital. Acta Neurol Scand 1998;67:235-241.

22. Fischsel H, Knopfle G. Effects of anti convulsant drugs on thyroid hormones in epileptic children. Epilepsia 2009;19:323-8.

23. Liewendahl K, Majuri H , Helenius T. Thyroid function tests in patients on long- term treatment with primidone anti epileptip drugs. 2008;1399(8):185-8. 